VISUAL ESSAY

\title{
Floating in Quarantine: Where Colourless Green Ideas Sleep Furiously
}

\author{
Luigi Russi* and Katarina Rothfjell ${ }^{\dagger}$
}

This piece is a collaboration between Venice-based photographer, Katarina Rothfjell, and Turin-based sociologist, Luigi Russi, both of whom experienced the onset of quarantine in Italy, in March 2020, in order to contain the spread of the Covid-19 disease.

An abrupt rupture in the conduct of everyday life punctures an atmosphere of safe expectations and reveals unsettling new proximities. First and foremost: the SARS-CoV-2 virus, which is ubiquitous but also invisible. Alongside it: the prehensile vapours where speech begins, and the erratic soundscapes that keep vibrating bodies together across open windows.

By charting these proximities, the piece strives to make visible the 'continuum' of bodies-human and nonhuman-as they 'take place' simultaneously, and affords a glimpse into how the possibility of agency might be imagined in a posthuman horizon, beyond the comforting human-centeredness of the Anthropocene.

Keywords: Covid-19; quarantine; posthuman; agency; Anthropocene

Greetings from the lazaretto -it's okay to feel lost. It's from that yawning gap of sudden loss that Katarina, a photographer based in Venice, and I, a sociologist based in Turin, venture for glimpses of articulation in image and word. 'This is happening to me, yet I feel like a spectator'Katarina's words echo within me like a bitter truth. The feeling of being dropped into the void is the elephant in the room, like that other 'stone guest'2 you can't seeCovid-19.

The fall. A rip in the reassuring atmosphere-of knowing what life is meant to look like day after day. When I think of the Anthropocene, I imagine a thin veneer of civility etching geological trails on the Earth's flesh-there's something reassuring in the image, a comforting sense of agency in digging cement foundations into solid ground. Corona brings floating back. It evokes a continuum where bodies keep shuffling together and about. Here, it's less a question of finding one's footing, than growing sea-legs to move with the currents (Buckingham 2019), to become sensitive to position (Grear 2017) and hone different organs of perception (Bortoft 1996) to respond to the calls of our surroundings, for another first time (Shotter 2000).

\footnotetext{
* Schumacher Society, UK

+ Photographer, IT

Corresponding author: Luigi Russi (Irussi@speedpost.net)
}

From the fall to a resurrected sense of position/ agency-quarantine enfolds it all. It intensifies the confused multiplicity out of which worlds surge for a time, and into which they collapse again. This is the turbulent place where colourless green ideas sleep furiously.

On Monday, 9 March 2020, the Italian government brought into force a Law Decree establishing a country-wide quarantine in Italy, in response to the alarming spread of Covid-19. You've heard about the virus already? I bet. Everyone knows Corona.

I'm still figuring my way into what seems a city-wide game of make-believe. These are the rules, as I understand them:

1. You occupy a sphere with a radius of at least one metre. Don't let others in your sphere, or Corona might get you.

2. No touching allowed. Don't hug or kiss other participants, or Corona might get you.

3. It's not a game.

It's not a game, no. But neither does it feel real to move around like a sphere. I'm a swift stream, and keep coming up against slow-floating bodies digging their feet into the pavement. 
I was floating by where I wanna be

-Floated by, $2019^{3}$

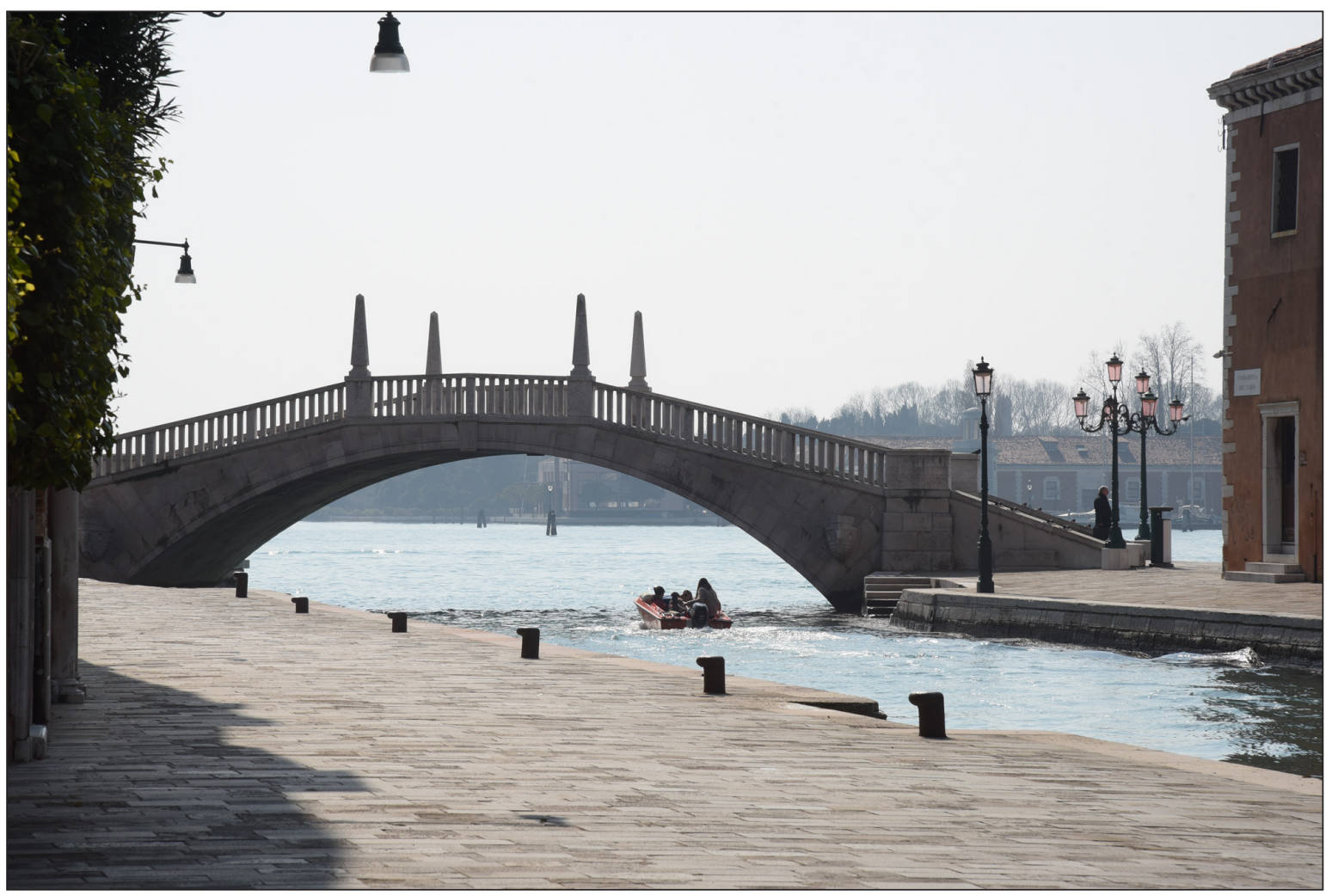

I can hear birds. And postprandial sirens. The silence. I hear that, too. Crisp as cessation-you know when urban cacophony drops its hum. I wasn't meant to be here-with a plane ticket for Thursday (12 March) and my life in a box, I had a safe ride to the outside.

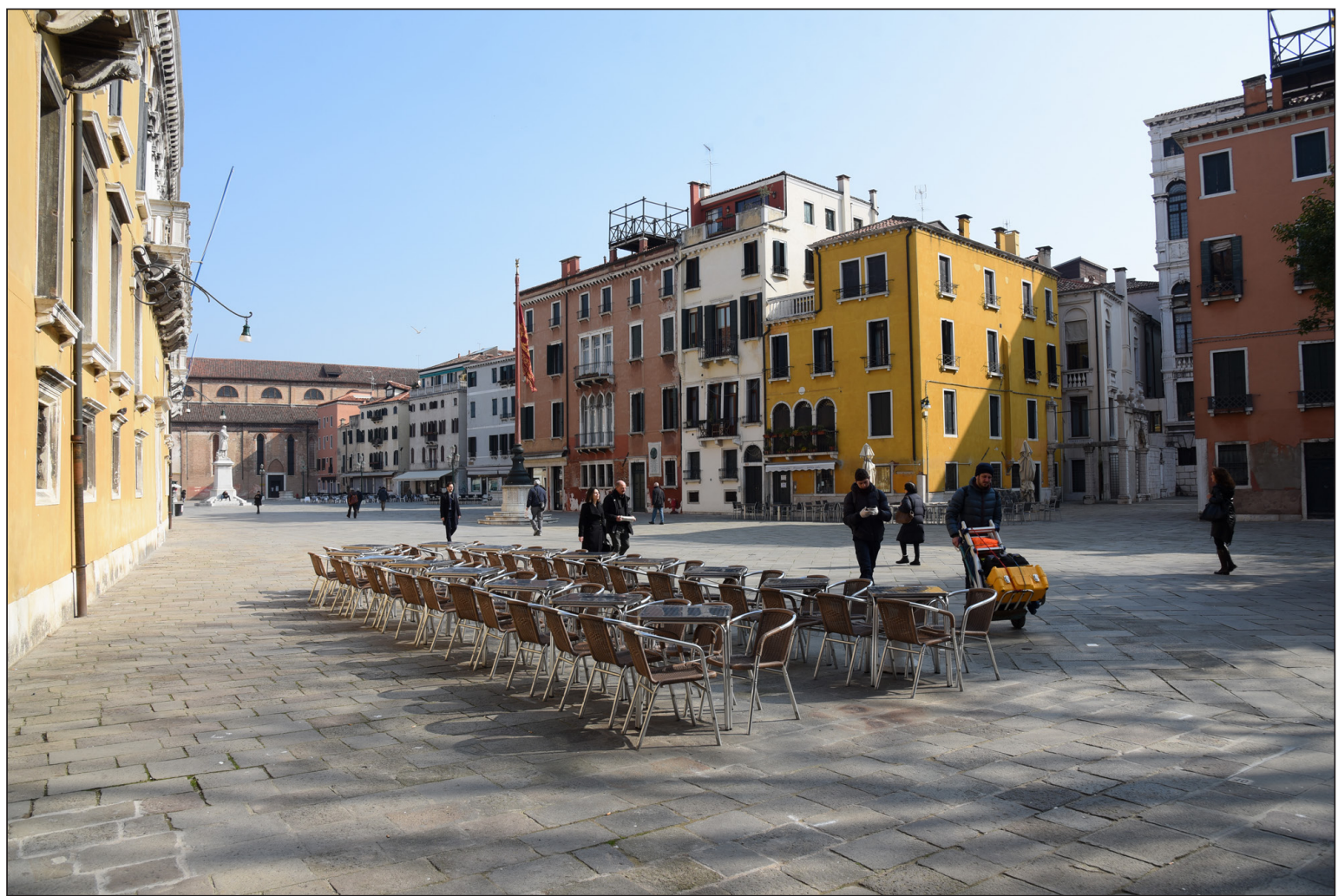

An old man drags his weight across the sidewalk. I want to overtake him, but we'd get too close-what if he coughs? So I slow down to his pace, keeping a distance behind him. At the first opportunity, I step down to the street and pass him on the other side of a row of parked cars. A little further along, a woman in a face mask moves out of the way so our paths don't cross. 
'It's not a game'-I repeat to myself, as Carlo resists Skyping and defiantly proclaims he'd brave the police to see me in person. People are being asked not to leave their homes unless for strict necessities (like going to work or shopping for groceries), and must produce a sworn declaration of the purpose of their outing if questioned by a police officer. I hesitate momentarily before Carlo's bravado.

Still, catch-me-if-you-can with the police is not it.

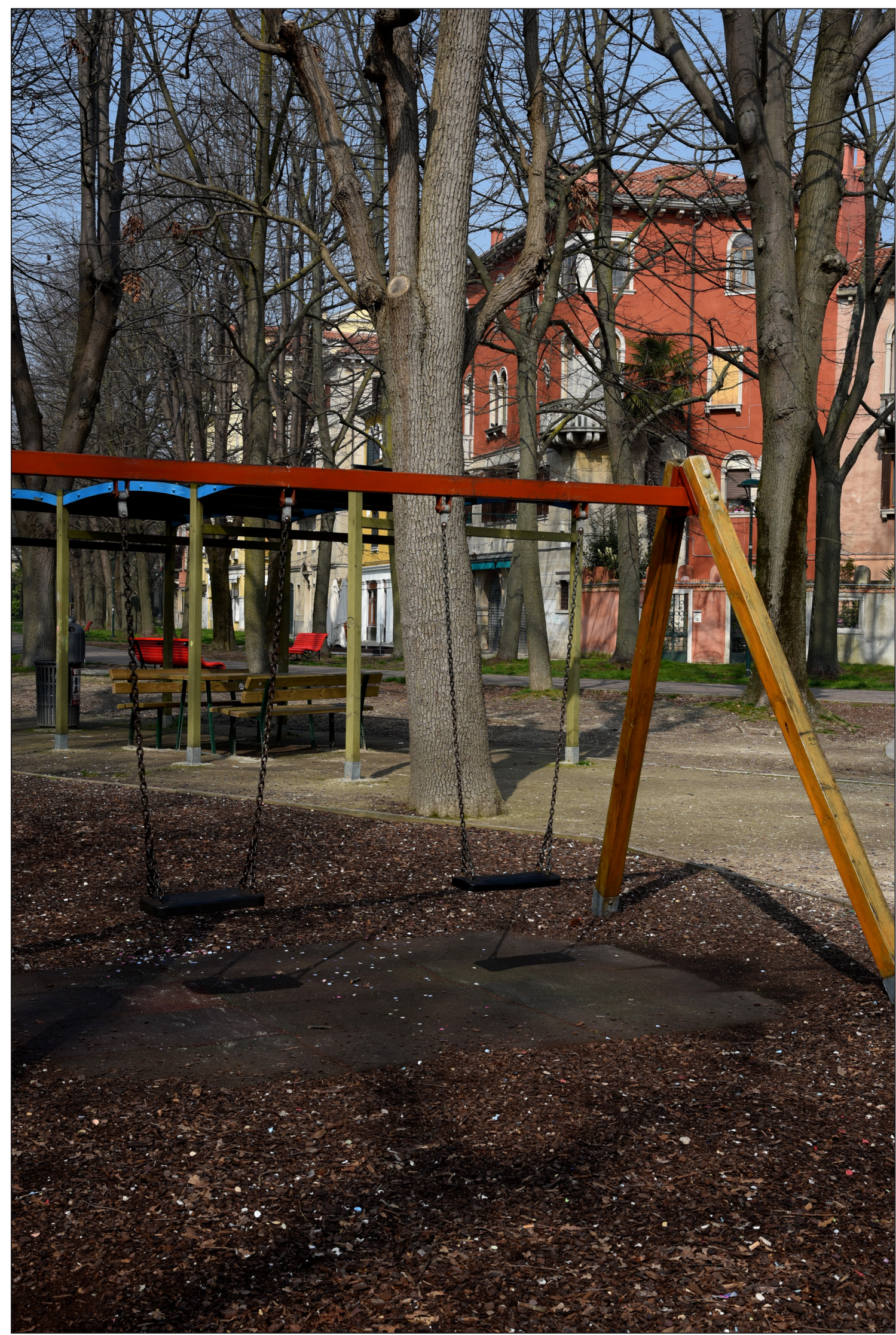

Parks are shut to prevent informal gatherings of people exercising in the open. It isn't a holiday, either. 


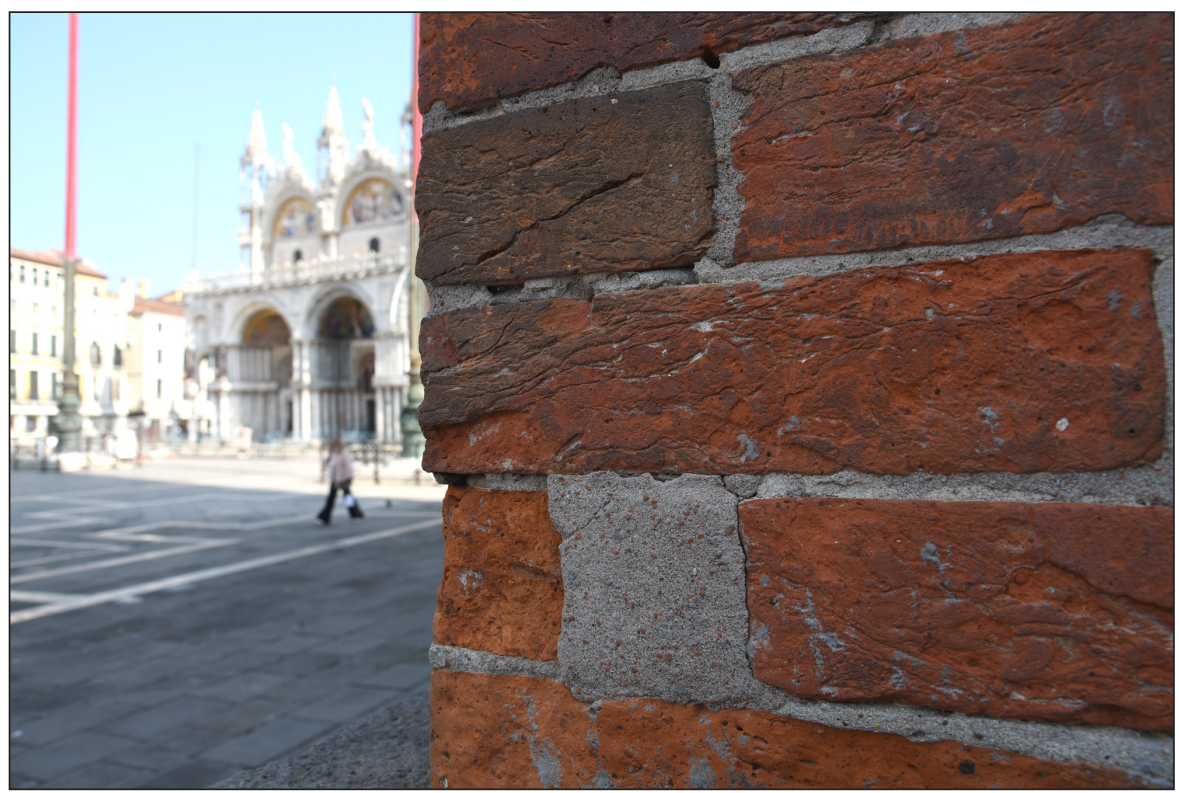

There's something raw and unadorned about it.

I'm not sure what it is, actually. I don't think I've visited this place before, have I?
It's like the thin veneer of civility has been scraped away; I have trouble recognising my own kind.

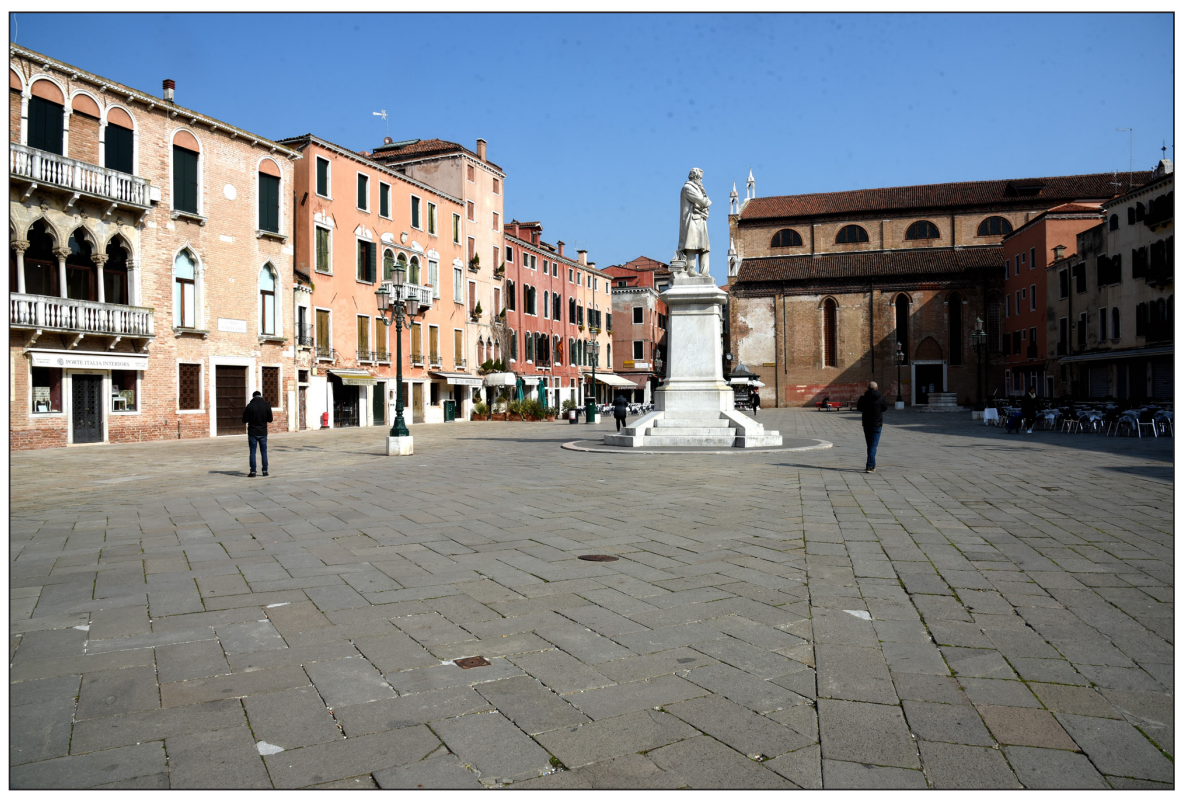

Bodies aloof and adrift, in no particular order.

This description comes close:

During the initial phases of schizophrenia, it is frequent for a whole set of transformations to emerge: transformations of experience and transformations of the usual perception of the world, of one's self, and/or of one's own body. These transformations often begin as subtle and diffuse modifications, which do not stem from delusional content strictly speaking, but rather from the impression of a change in the general ambience that surrounds the subject (Troubé 2013).

In a word: Wahnstimmung. Ercolani (2010: 12) defines Wahnstimmung as the "emotional storm" giving rise to a zone of turbulent ambivalence'. I feel this comes close to how I experience the abrupt onset of quarantine: a sudden volatility, like having the world slip from view behind the moving blades of a fan. F. F. F. F. F. The world disappears from view long enough to doubt it's really there, but not enough to notice the blades that tear at it. There's just something in the air.

Wahnstimmung evokes the raw flesh that shows, like an unknown geological layer, after the veneer of meaning and civility has suffered a rip. I believe this is the place Chomsky (1957: 15) might have inadvertently had in mind when he came up with 'colourless green ideas sleep furiously.' For Chomsky, this sentence approximates nonsense-if read literally. That's not far from how quarantine can feel, when it is also taken literally as a space of pure negativity-of simple denial of any possibility for action. 


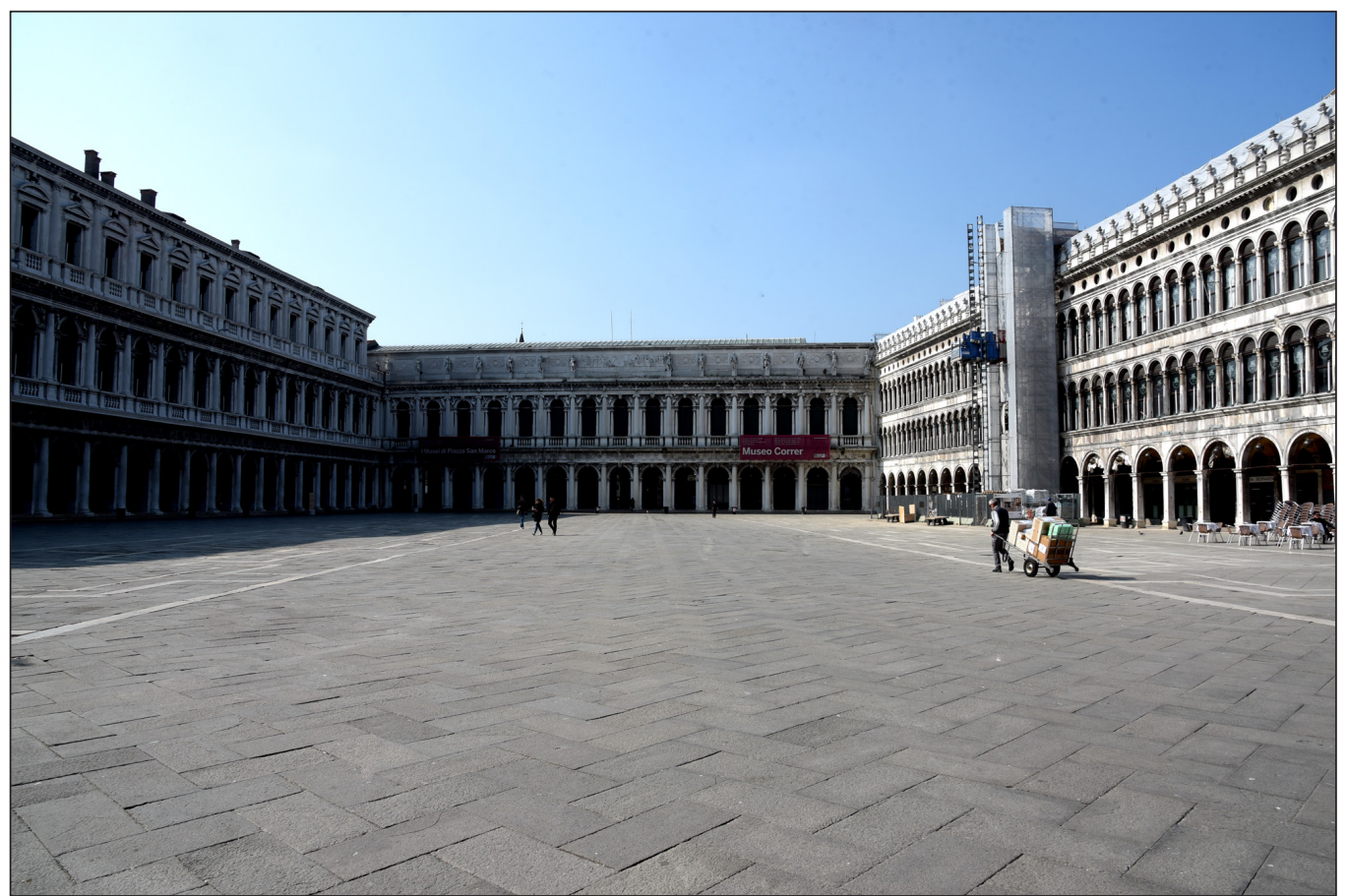

Literality is a square enclosed on all sides. A perimeter that opens nowhere. An already-finished world.

This space of pure negativity conjures an absence: of 'normality,' of work as usual, of a sealed panic room to keep yourself from hyperventilating. As a radical measure, quarantine is the remedy of last resort that announces a wound, that proclaims the absence of a reassuring normality (Bashford 2020).

Yet, to take quarantine literally, as only an absence, is tantamount to speaking from the perspective of the floating skip below, a place where work seems to go on undisturbed, untouched by the outside. Life in the skip assumes we can always stand above the current, without touching it. This is nostalgia for the hug of a secluded atmosphere (Philippopoulos-Mihalopoulos 2016). As if mending the rip that transpires through quarantine could push the raw layers forever out of sight, and bring one back to a world that is forever unperturbed from the

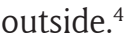

To find one's bearings in quarantine is not a matter of searching for solid ground to stand on-maybe that was always just an illusion. Instead, it is a question of learning to float on strange currents. From this view, quarantine

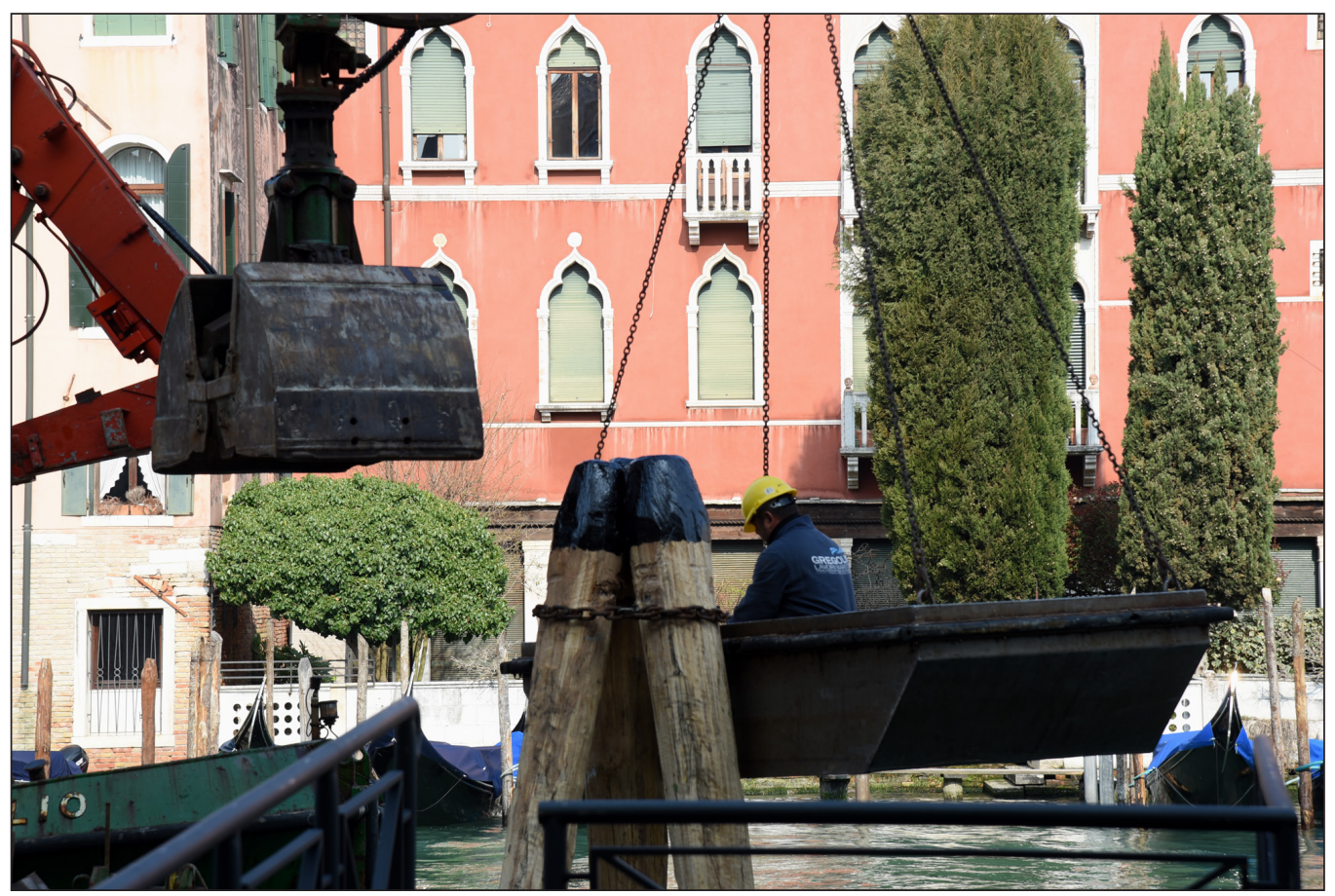

Hanging above water isn't floating. 
might be likened to Esquirol's asylum, a place where the ubiquitous paradoxes of normality are simply visible more clearly: "in such a house the traits are more vivid, the colours more alive, the affects bear more contrast, because man shows himself in all its nudity, does not dissimulate his thought, does not hide his defects' (Esquirol 1982, cited in Ercolani 2010: 17). On the back of this association, quarantine might then be approached as more than just an absence-more than just the negative of atmosphere. Like Esquirol's asylum, quarantine folds everything that already is, making more visible the nimble work involved in staying afloat-a work that takes place all the time.

Following Shotter (2004), the work of 'making oneself at home' amidst changing currents is always already occurring, as bodies dwell alongside other bodies. Temporary islands of coordination emerge out of the confused entanglement of bodies with one another:

the pulsating flow of spontaneously unfolding, reciprocally responsive inter-corporeal, inter-activity, between us and our surroundings - a whole background flow of activity that happens to us, and in the context of which, what we choose to do takes place and has its significance (2004: 444). ${ }^{5}$

This means that there is always 'something' going on, as bodies respond spontaneously to other bodies. It brings back into view the already ongoing currents of prelinguistic activity in which we find ourselves immersed. Pure negativity, the absence of atmosphere, is just a trompe l'oeil. Tuning back into life as a tangle of binding and corresponding lines (Ingold 2008) demands one to take a poetic-not a literal-approach. This shift makes it possible to imagine that the oily, colourless green of Venetian waters might stand for our tumultuous preverbal entanglements: stuff that sleeps furiously-and occasionally shimmers in the light. When this maelstrom comes into view, the bearers of mankind's original poetic wisdom are awakened in us, they who expressed their very violent passions by shouting and grumbling' (Vico 1984: 116). I imagine they, too, must have slept furiously over murky intuitions of bodily leanings and attachments to the others and othernesses calling out to them.

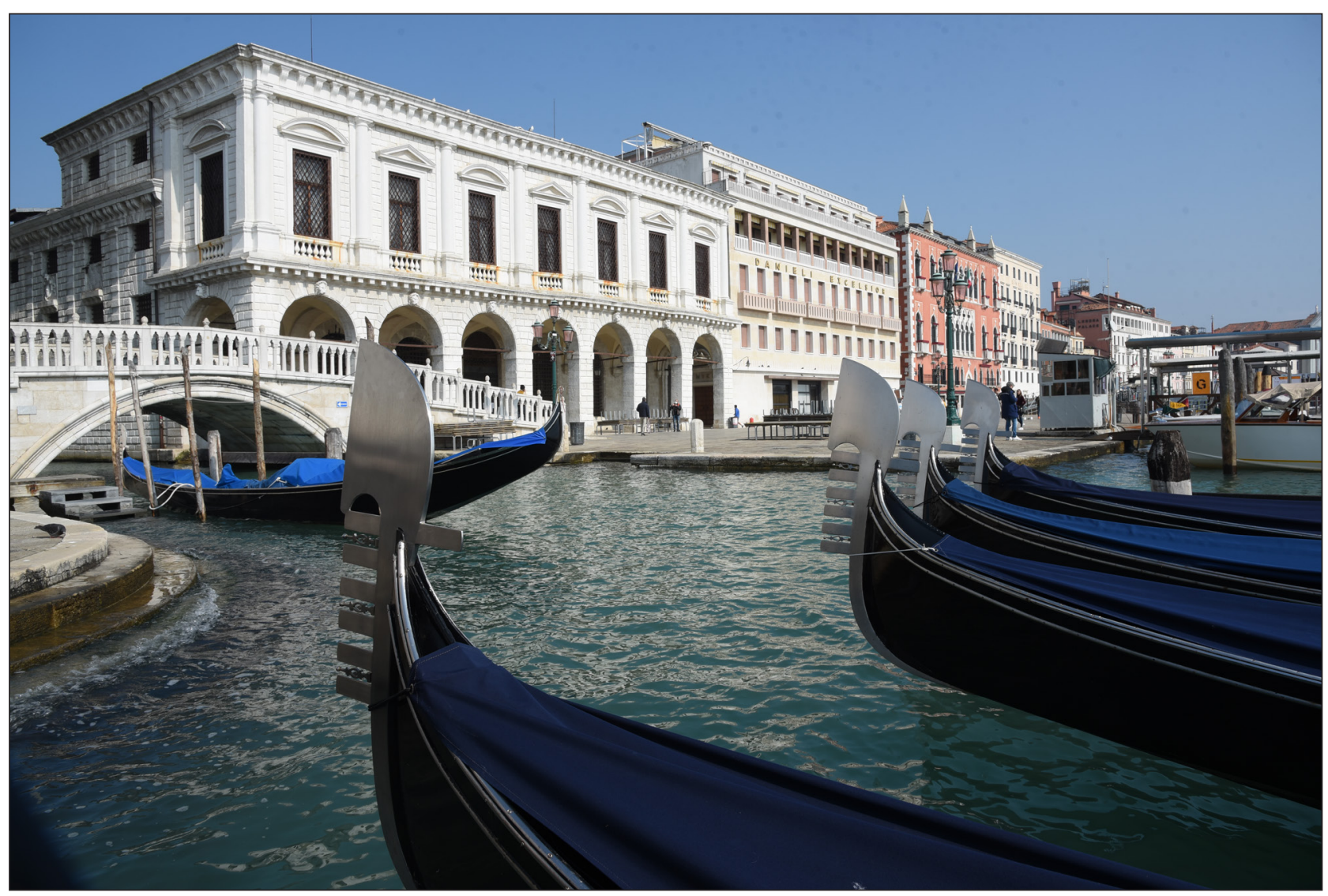

Floating. That instant when the bow lifts elegantly, as currents lap at the hull. 
Dwelling in quarantine, regarded as more than a purely negative void, means beginning to name 'real presences' in our midst that we previously had no names for. It's beginning to engage in the work of getting to know them, and getting to know ourselves yet again, shuffled into different configurations by new entrants.

One of these presences is, in fact, Corona. The Cartesian virus, which demands disembodying the prehensile, vaporous beginnings of speech into fully-formed words spoken behind screens (so they don't get you wet). I never realised that speech bursts forth in a cloud of spittle-that it is originally vapour and humidity. That is the space Corona reveals to me, at the same time as it quarantines me to face-to-face Zoom calls where the gasps, the uhm's, the sighs from which speech originates are harder to notice. I never before experienced how the beginnings of speech are less to be listened to for meaning, and more to be intuited through bodily proximity. Corona separates out the messiness of relating in a nebulous proximity that we inhabit nebeneinander (side by side), into terminals located at opposite ends of a phone line or a screen. My body wails at the loss.

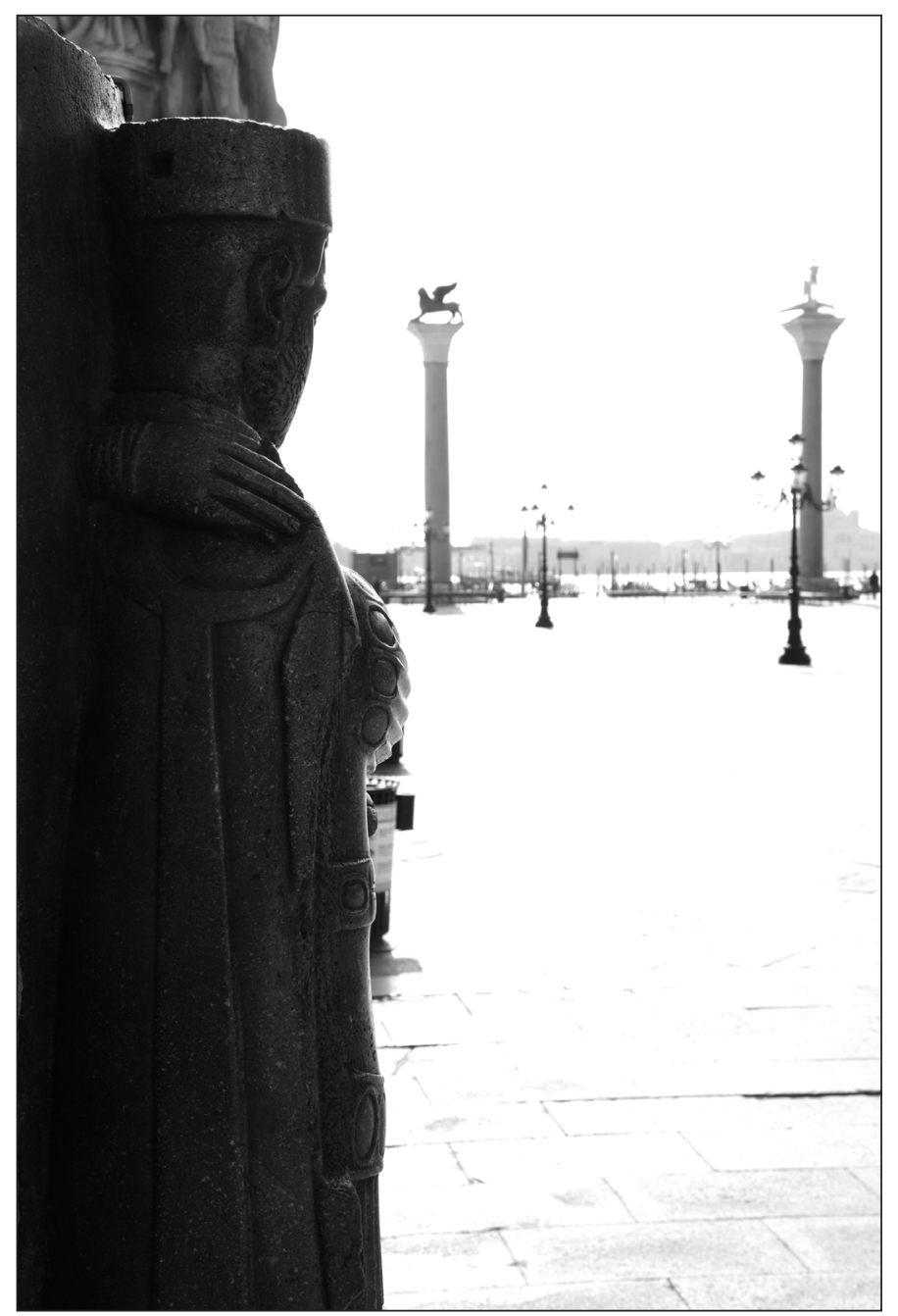

The 'stone guest' you can't miss/can't see. Its unexpected appearance-Cartesianism personified in a viral affect-mops up the suffused vapours of speech into strings of words transmitted telematically.

Corona quarantines you to Zoom calls in the house of 'little b' being, while stopping speleological explorations in the folds of 'Big B' ${ }^{6}$ Being (Shotter, 2016)-its lunar caverns locked under little-visited layers of embodied experience. There is surely more to communication than transmitting already worked out messages from opposite ends of a line. Instead, speaking and listening occur-together-inside a nebulous continuum where speech surges from a vibrating field of vague pre-verbal sensings (Lipari 2014). The memory of 'live' speech (of the pre-Covid-19 sort) now tastes like a mysterious hum from which extraordinary forms would sometimes rise. I compare it to a cavern. Caverns, so I've heard, often house awe-inspiring rock formations generated by primordial gases, not of this atmosphere, that have stayed locked in the depths. Quarantine makes me yearn to catch another glimpse of the stirring, otherworldly, cavern-like formations that arise ephemerally in 'live' speech. I feel as though I were lying in wait inside a cave-like the biblical Elijah-in the hope of meeting again the whispering trail of silence before words, before the Anthropocene. 


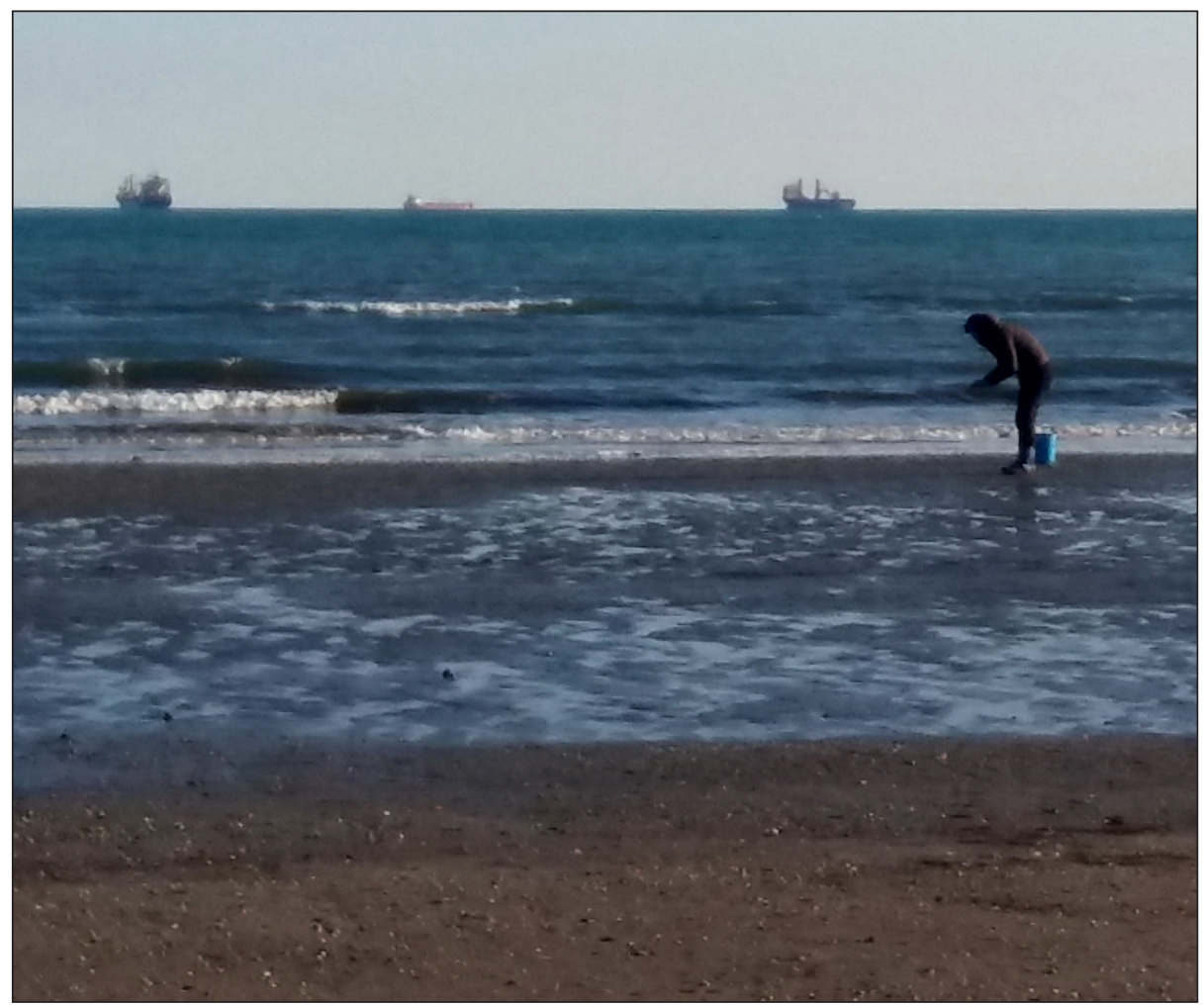

Speech/spittle. To listen is to get your feet wet in a lapping tide. And to pick up the shells it brings ashore, with the awe of a new creation-life is passing, providential form pressed into the thirsty palms of waiting shores.

(Bethsaida. A blind man once had spittle pressed into his eyes, and was no longer blind).

To remain. Mary Magdalene remained before an empty tomb, until she heard a calling from behind, just when her sight was impaired by tears-Rabboni! (Rambo 2010). Resurrections happen by dwelling awhile in abandoned places. New organs of perception grow and sharpen, till unseen presences finally catch our attention-obliquely. There are many nuances to nothingness (Souffrant 2017).

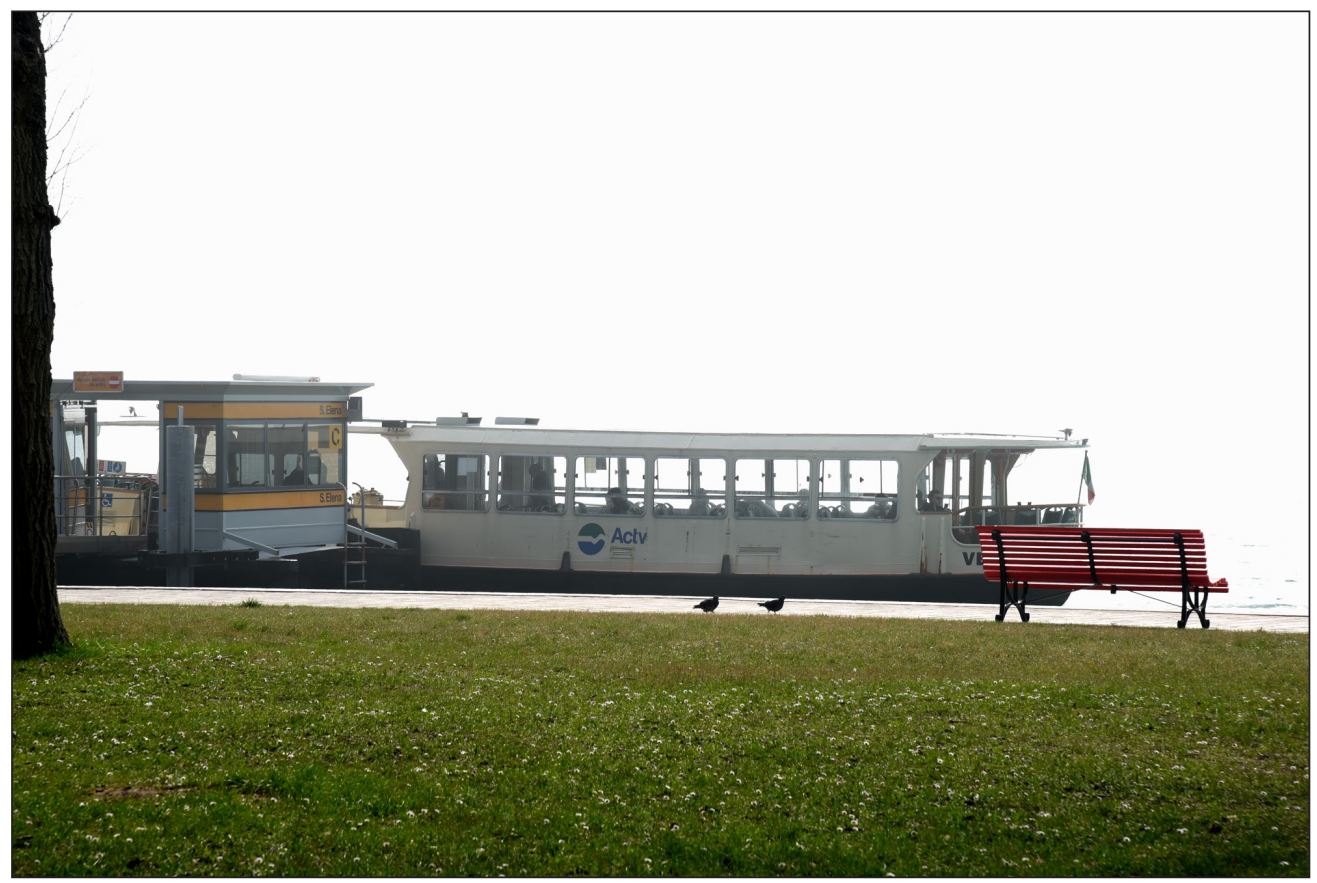

All I see, as I examine the picture from my desk in Turin, is the empty bench. Till Katarina draws my attention to the windows of the vaporetto (the Venetian bus), with its cargo of spectral absences. Hollows don't reveal themselves to an untrained eye-it takes patient work to grow a new discriminative sense, to find names for the features of our surroundings that spontaneously 'activate' our attention. 
As eyes adjust and ears tune in, rivulets surface through the cracks. We begin to notice those next to whom our life might go on. Proximity with other bodies continues-that, truly uninterrupted-even in quarantine.

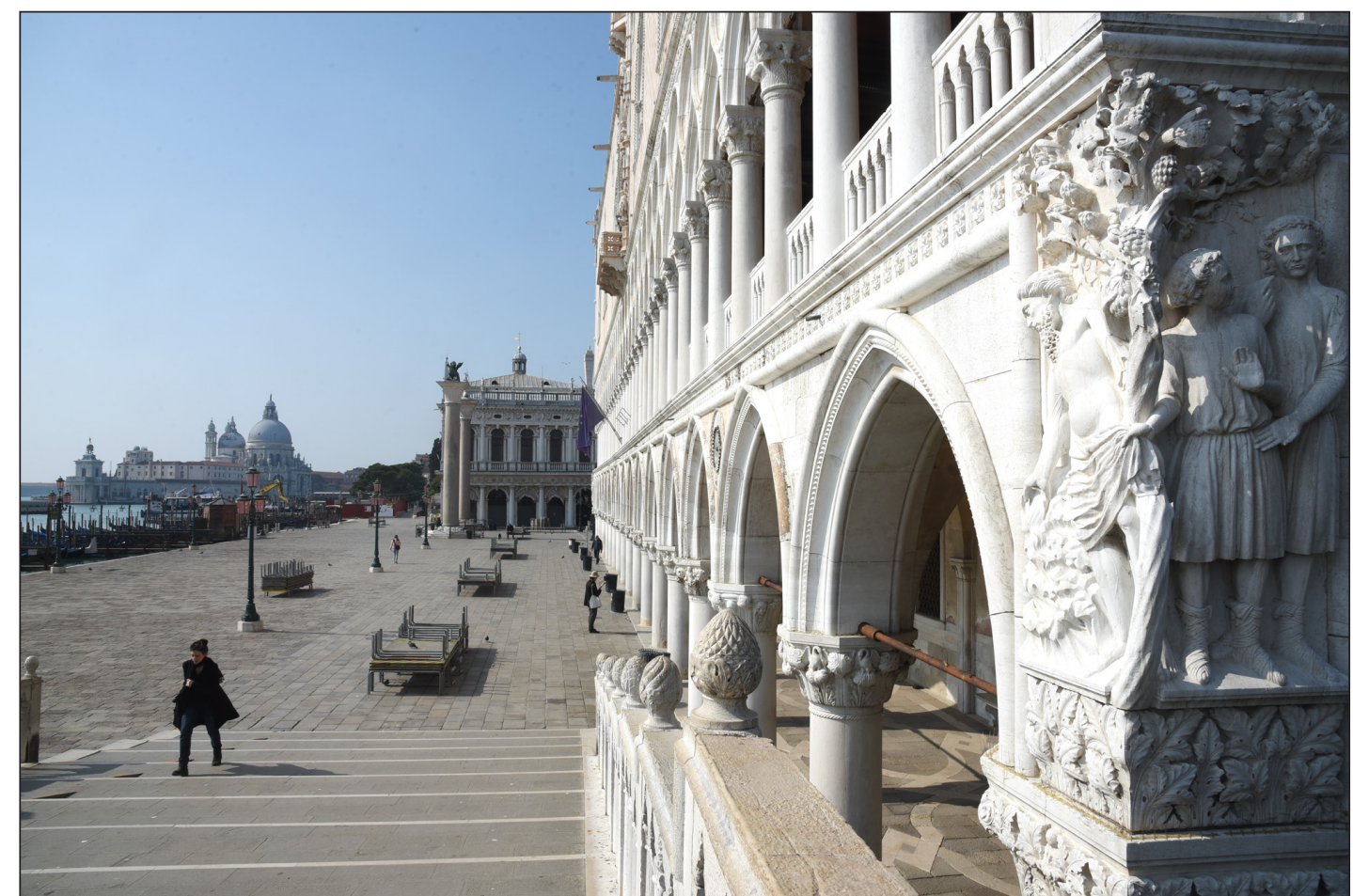

Adjacent presences keep whispering in the background. They carry a memory that our work hasn't stopped. Something remains-always.

This is orienting to the calls in our surroundings 'for another first time.'

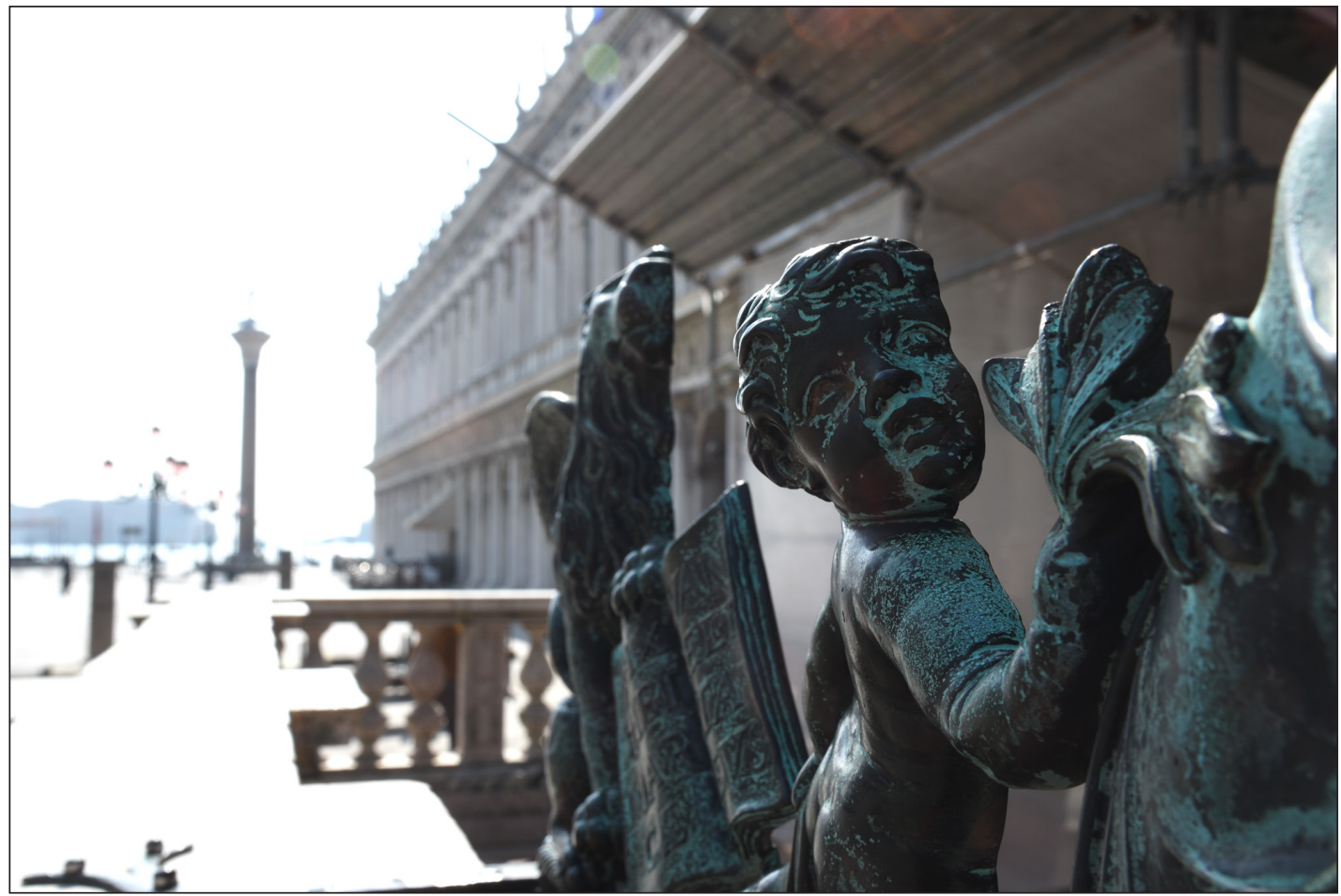

I hear clapping. An elderly lady is clapping at her dog on her balcony. A young couple surge from behind a flag-he claps. I clap in response. White heads venture out of the blinds opposite. They clap. A bald lady is brought out onto a terrace by her carer. Chemotherapy. Clap. Something stirs. Clap. A mother opens the window for restlessly curious eyes. They, too, clap. All these faces live here. Clap-clap-clap. This is what 'orienting to the calls in our surroundings for another first time' means. Clap. I come back to my desk-tears stay with the event that just flowed, as it slowly ebbs away. 
New vapours exude like stardust, this time through open windows. Quarantine begins to draw one into new entanglements, into an awareness of position that slowly dawns. It entails learning to name that which we discover ourselves to be already moving within, a soundscape of strange waves that began visiting our shores before we even had ears to hear.

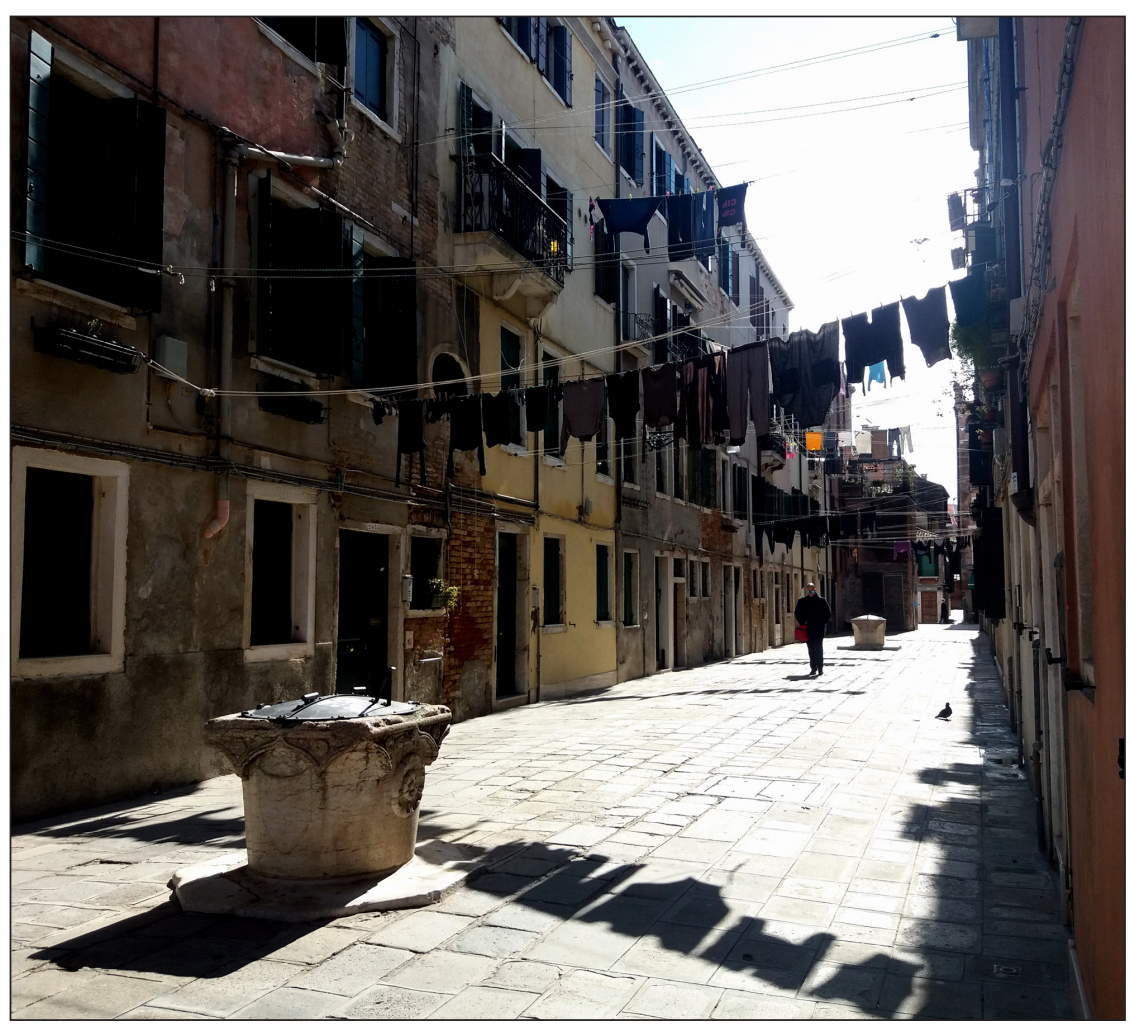

'Si stat' ... 'o primm' ammore ... o primm' e ll'ùrdemo sarraje pe' mme' blasts from an open window. Forza Napoli!

The unmistakable pitch is Massimo Ranieri: my father's favourite. Meridionali where you'd least expect them. The chorus surges in my diaphragm, I want to belt it out, but I'm self-conscious. 'O surdato 'nnamurato (1972), my late grandmother's signature song, woke her out of dementia-in a different sort of quarantine-during one of our last real moments together. Something opens. Exhilaration bubbles in me, like a quickening. Maybe, within a couple of weeks, this street will not look too different from a vascio in the Spanish Quarter of Napoli. ${ }^{7}$

A crowd of private lives entangling fearlessly, and furiously, as they correspond through open windows.

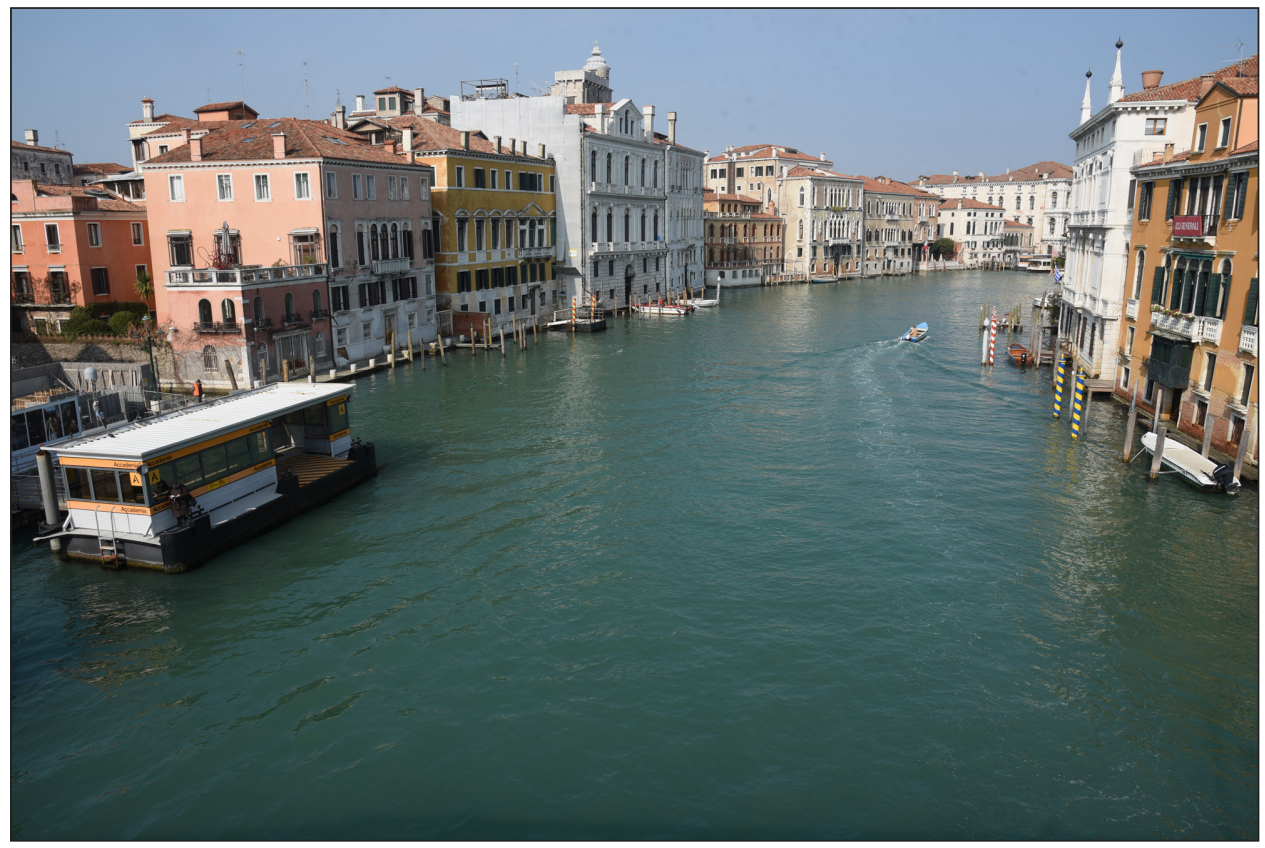

There is no outside, only currents to float with past the bend. Breathe. 
Maybe I was always there

-Floated by, 2019

Life in and out of quarantine is being constantly re-folded on a shifting vibrational continuum of riffs and hums that-like music from a neighbour-pass through porous walls. There is no outside in this continuum:

Whether you are a quark, an amoeba or a person, you undergo this continual process of sorting through these three inputs: what you inherit from the world, what's possible in your context, and what you do about it. This is the cause of our freedom. We are not bound by the past. It is not a deterministic system. We can do something new (Coleman 2008: 51).

Yes, bodies together are always onto something new-and that's the cause of our freedom.

\section{Coda}

It's been two weeks since the expansiveness of that last breath. Two weeks I have spent in a small flat, with little natural light, its floor bearing the marks of heavy pacing-like 'Il Consorzio' beach below, once the commotion has faded and only crumpled traces remain in its wake. I've tried leaving the quarantine once more. Yet again, my flight has been cancelled. As I go over the reviewers' feedback to the first draft of this piece, I feel I have lost touch with the silver lining that gifted me a sigh of relief a page ago. Today, I'm speechless again. So much so, that I don't know how to respond to this comment, by one of the reviewers, because it opens a breach I am unable/unwilling to close:

Having had to find our own bearings in 'lockdown' conditions, the account given by the piece now has to compare with our own [the readers'] experience; and it may not (does not) resonate. ... confinement may not be experienced as a void; rather, it may be all too concrete and familiar, oppressive rather than empty (italics added).

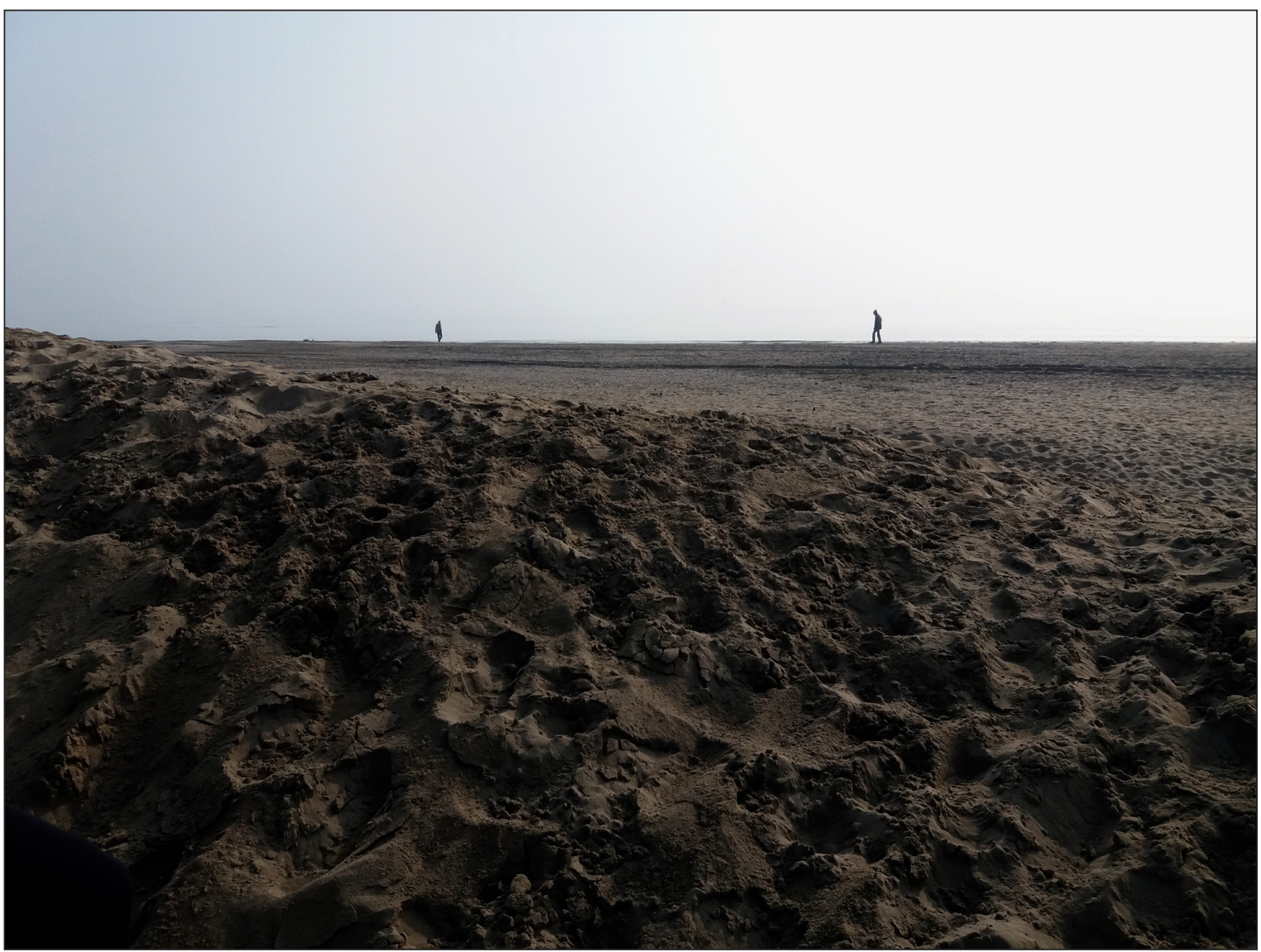

A gaping wound in the sand, quarantine reveals jarring sights of inordinate folds. Moments of spaciousness and floating fold back into dried up craters.

The 'metaphors used in the text are often infelicitous,' especially since 'word and image do not yet build on each other's missives sufficiently to create a convincing

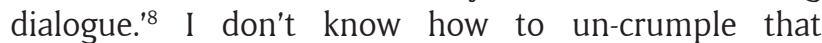
which cleaves too closely without leaving any space. This contraction of speech that at once packs in too much and says too little: how might that bear a trace of the experience of quarantine? What if the reviewer's dissatisfaction could help amplify the cacophonous quality of quarantine, in which 'sentences [do!] begin to read like "colourless green ideas sleep furiously"'? 
'Colourless green ideas sleep furiously' is a grammatically correct sentence, which ostensibly means nothingthis is Chomsky's claim. Read in quarantine, I argue it gestures to a perturbed continuum of spontaneous bodily responses that suddenly make it to the surfaceall at once-and remind me of the oily Venetian waters lapping, half menacingly, at gondolas. In colourless green waters, an omen sleepy and furious at the same time, floating on currents might move one past the bend for a while, before leading one back to the quicksand of encountering irreducible otherness-of being stared at silently, as if by the mouth of the canal below. A position is possible, but it does not grow into a stable footing-it falls away quickly in the breath of just a page.
This piece came to be by allowing Katarina's images to unsettle me. Photos drew speech out. Like a clam, however, my speech remains encrusted with all sorts of seaweed, so it is not always easy to open. This, I think, is what the aforementioned reviewer has picked up. It's a strange, cacophonous sort of utterance.

Bringing this process back to memory, however, helps me better articulate the experience from/of which this piece speaks. The sites of Venice portrayed in Katarina's photos have not spoken to me as sights of Venice (I have only visited Venice once, years ago). Rather, as I let myself be unsettled by them, they intensified certain feelings that quickened violently and mutely as I shivered with the rapidity of quarantine. Quarantine eventually spoke to me through the walls and canals and waters and boats of Venice-it was like being simultaneously poured outwards yet deeper inwards, folded in a Moebius strip.

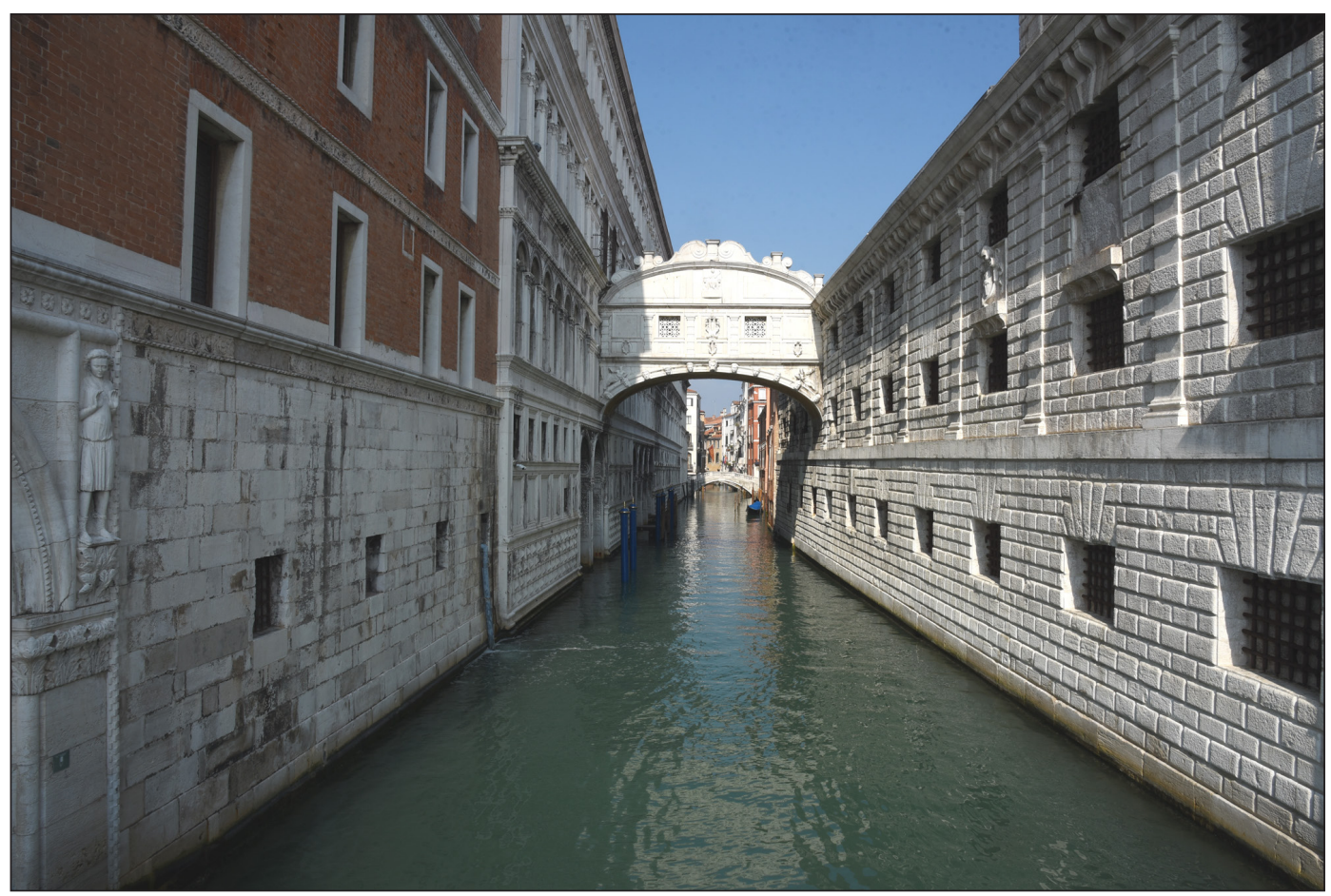

'Yes, bodies together are always onto something new and that's the cause of our freedom-and our confinement'. ${ }^{9}$

Composing this piece has allowed me to experience more closely the contrast offered by materiality in its unspeaking thickness, staring at me from the back of Katarina's photographs. This endeavour has alerted me to a possible way of working, as a body alongside other bodies, with 'objects that object' and stir and unsettle me. Other bodies intensify what's already bodying forth somewhere in my senses, they draw forth resonances by which I might sound that out-just as I lean on a veined brick, on disturbed sand, on ruffled streams.

What is intensified in me, then, as I lean on/away from SARS-CoV-2? The unpredictable, bat-like presence of a virus of which the best-known attribute might be its elusiveness and ubiquity. I have found dealing with it a test of sanity. Speaking of sanity, Ercolani (2010:30-31) gets close to the precarity of any grip one might have on it:
Madness means to experience without interruption the condition of being 'eradicated' from the world. Becoming an artist is to manage this condition, only just, to experience it not as prophecy, command, revealed truth, but as a repository of images, sounds, compositions-inexhaustible source of a thousand truths yet to be revealed.

This piece is in a way a meditation on how finding agency in the Virocene might be inextricable from an experience of becoming de-centred, ${ }^{10}$ of unclasping one's grip on sanity, of speaking inarticulately when confronted by material presences that stun and perturb. Standing is not afforded, here, by solid Anthropocen-tring ground, but by the craft or artistry of growing sea-legs that sometimes 
move with the currents, and just as often get one bogged down in quicksand.

I have chosen to end the piece with 'graffiti' conveying a reviewer's voice that's not my own, a voice I found both disturbing and revealing, because it creates a fracture. It fractures the tapestry I had carefully woven, as I tried to find my own footing in quarantine. As I end this piece, the sense of knowing where I stand is gone again. This, however, brings into question the distinction between having a centre and finding a position. The Anthropocene, by positing mankind as prime mover, 'takes centre'. In the wake of slipping from that centre, one might only find a position, and then experience it falling away again. Being able to track the rising and falling of our bearings, without trying to consolidate centrality-this is the ethical crossing that SARS-CoV-2 seems to invite. It evokes work of a difficult sort: that of attuning to bodies that draw forth our response, at the same time as they rupture it.

\section{Notes}

${ }^{1}$ An isolation hospital for people with infectious diseases.

2 'Stone guest' is an expression adapted from the title of one of Tirso de Molina's plays, namely The Trickster of Seville and the Stone Guest (Edwards 1986). The play revolves around the encounter between Don Juan, the protagonist, and the statue of the deceased Don Gonzalo, whom Juan has murdered. The statue of Don Gonzalo constitutes a mute and menacing presence, which-through being taken too lightly by Don Juan-ends up causing the latter's demise. The term 'convitato di pietra' (stone guest) has become an Italian idiom for just such an eerie presence that might be at work in a situation, albeit without it being possible to see exactly how it operates. It is an apt metaphor for the agency of the SARS-CoV-2 virus, the presence of which is palpable, though hard to witness.

${ }^{3}$ Peter Cat Recording Co (2019). I'm indebted to Anna Lena Hahn for suggesting 'Floated by' as an added layer, to listen for the mood sketched by the text and images. There's something sleepy and furious about world-weary trumpet riffs.

${ }^{4}$ Philippopoulos-Mihalopoulos (2016) uses the word 'atmosphere' to describe an arrangement where the outside is recreated in domesticated form, thereby reinforcing a desire to remain enclosed within. I have elsewhere (Russi 2016) compared this to M. Night Shyamalan's The Village, where Amish villagers never want to leave their dwelling for fear of monsters inhabiting the woodland that separates them from the wider world-which monsters turn out to be some of the villager elders themselves, dressed in a costume. The picture of a suspended skip reproduced in the text also provokes some thoughts on the 'vaccination' to come(?). Inoculation with a weakened version of the virus, a simulacrum of SARS-CoV-2, will likely make it possible for life to go on again, unperturbed. This is an example of how, despite everything, atmospheres make a version of life possible, even though this is achieved by confining otherness to manageable harbours, in such a way that the delicate and hazardous work of floating on open waters-the work of withdrawalrecedes in the background, and takes on the status of something to be avoided at all costs. Perhaps, Philippopoulos-Mihalopoulos' (2020) suggestion that the Covid-19 pandemic ushers in an 'ethics of withdrawal' points to exactly this: to a world where the work of withdrawal needs to be met again. It's precarious, risky work. The fact that it is precarious and risky gives it away as precisely a work of withdrawal-that is, laced with the painful rupture of a lingering desire for sameness and predictability.

${ }^{5}$ Shotter uses the term 'inter-activity' here, as if to suggest entities separate from each other. He later took up Barad's (2007) suggestion to use 'intra-activity' to emphasise co-emerging sites of activity in the folds of a continuum (Shotter 2014).

${ }^{6}$ Shotter (2016) articulates a tension between 'little b' being and 'big B' Being, as a way to distinguish between experience that's been domesticated and thematised into language ('little b' being), and the background, pre-linguistic sensings with which language has to reckon, but can never fully express ('big B' Being). His use of this terminology-and particularly 'big B' Being-is drawn from Heidegger (1977).

${ }^{7}$ A vascio is a type of ground floor dwelling overlooking the narrow alleyways of the Spanish Quarter of Napoli (Celotto 2012). The atmosphere of the vasci is characterised by an uncommon display of private lives through open windows.

${ }^{8} \mathrm{I}$ am reproducing comments from an anonymous reviewer of this piece.

9 This is a verbatim quotation from the response to this piece by an anonymous reviewer. It is not my conclusion, and I do not wish to pass it for mine. Still, I'd like to own it: it dissipates the illusion of positionit only lasted a breath after all.

${ }^{10}$ The sense of de-centering evoked by the relinquishment of human centrality in favor of situatedness on a continuum with other bodies is conveyed powerfully by Graziano Panfili's photographic collection 'CORONAVIRUS: Postcards from Italian webcams' (Panfili, 2020). Panfili's 'postcards', captured from the unusual angles policed by webcams, offer equally unusual takes on popular tourist sites, conveying a sense of dislocation, of slippage, of an unstable frame.

\section{Competing Interests}

The authors have no competing interests to declare.

\section{Author Contributions}

While the final project has been approved by both authors, the text was drafted by Luigi Russi, while the photographs were supplied by Katarina Rothfjell.

\section{Author Information}

Luigi Russi is a Turin-based sociologist, and co-convenor of the Research-in-Action Community, Schumacher Society.

Katarina Rothfjell is a photographer based in Venice, Italy. 


\section{References}

Barad, K. (2007). Meeting the Universe Halfway: Quantum Physics and the Entanglement of Matter and Meaning. Durham, NC: Duke University Press. DOI: https://doi. org/10.1215/9780822388128

Bashford, A. (2020, March 6). Beyond quarantine critique [Blog post]. Retrieved from http://somatosphere.net/ forumpost/beyond-quarantine-critique

Bortoft, H. (1996). The Wholeness of Nature: Goethe's Way of Science. Edinburgh: Floris Books.

Buckingham, W. (2019). Finding our Sea-legs: Ethics, Experience and the Ocean of Stories (2nd edition). Leicester: Wind \& Bones.

Celotto, C. (2012). 'O vascio: Breve storia dei 'bassi' napoletani [The vascio: A concise history of Neapolitan 'bassi' dwellings]. Napoli: Intra Moenia.

Chomsky, N. (1957). Syntactic Structures. The Hague: Mouton.

Coleman, M. (2008). Making a Way Out of No Way: A Womanist Theology. Minneapolis, MN: Fortress Press.

Edwards, G. (1986). Tirso de Molina: The Trickster of Seville and the Stone Guest. Liverpool: Aris \& Phillips.

Ercolani, M. (2010). L'opera non perfetta: note tra arte e follia 1999-2009 [The imperfect work: notes between art and madness 1999-2009]. Florence: Nicomp Editore.

Grear, A. (2017). Foregrounding Vulnerability: Materiality's Porous Affectability as a Methodological Platform. In A. Philippopoulos-Mihalopoulos \& V. Brooks (Eds.), Research Methods in Environmental Law: A Handbook, 3-28. Cheltenham: Edward Elgar. DOI: https://doi. org/10.4337/9781784712570.00007

Heidegger, M. (1977). Letter on Humanism. In D. F. Krell (Ed.), Basic Writings, 190-282. San Francisco, CA: HarperCollins.

Ingold, T. (2008). Bindings against Boundaries: Entanglements of Life in an Open World. Environment and Planning, 40(8): 1-16. DOI: https://doi.org/10. 1068/a40156

Lipari, L. (2014). Listening, Thinking, Being: Toward an Ethics of Attunement. University Park, PA: Pennsylvania State University Press.

'O surdato 'nnamurato [Recorded by Massimo Ranieri] 1972. On 'O surdato 'nnamurato [MP3 file]. Milan: CGD/EastWest.

Panfili, G. (2020, March 16). CORONAVIRUS: Postcards from Italian webcams [Blog post]. Retrieved from
https://www.grazianopanfili.com/Postcards-fromItalian-webcams

Peter Cat Recording Co. (2019). 'Floating by' from Bismillah [MP3 file]. Lasne: Panache Productions.

Philippopoulos-Mihalopoulos, A. (2016). Withdrawing from Atmosphere: An Ontology of Air Partitioning and Affective Engineering. Environment and Planning D, 34(1): 150-167. DOI: https://doi.org/10.1177/ 0263775815600443

Philippopoulos-Mihalopoulos, A. (2020, March 13). Covid: The ethical disease [Blog post]. Retrieved from https://criticallegalthinking.com/2020/03/13/ covid-the-ethical-disease

Rambo, S. (2010). Spirit and Trauma: A Theology of Remaining. Louisville, KY: Westminster John Knox Press.

Russi, L. (2016). 'a legge d'o munno-Three Sketches on Spatial Justice. Global Jurist, 16(1): 1-25. DOI: https:// doi.org/10.1515/gj-2015-0003

Shotter, J. (2000). Wittgenstein and his Philosophy of Beginnings and Beginnings and Beginnings. Concepts and Transformation, 5(3): 349-362. DOI: https://doi. org/10.1075/cat.5.3.05sho

Shotter, J. (2004). Responsive Expression in Living Bodies: The Power of Invisible 'Real Presences' Within our Everyday Lives Together. Cultural Studies, 18(2-3): 443-460. DOI: https://doi.org/10.1080/09502380 42000201608

Shotter, J. (2014). Agential Realism, Social Constructionism, and our Living Relations to our Surroundings: Sensing Similarities Rather than Seeing Patterns. Theory and Psychology, 24(3): 305-325. DOI: https:// doi.org/10.1177/0959354313514144

Shotter, J. (2016, March). Deep Dialogicality, Human Becomings, and Leaders as 'Founders of Discursivity'. Paper presented at the Qualitative Research in Management and Organization Conference, Albuquerque, New Mexico, USA.

Souffrant, L. (2017). Plain Burned Things: A Poetics of the Unsayable. Liège: Presses Universitaires de Liège.

Troubé, S. (2013). Subjective Experiences of Emerging Psychosis: An Interface between Clinical Practice, Phenomenology and Neurocognitive Models. Recherches en Psychanalyse, 16(2): 144-153. DOI: https://doi. org/10.3917/rep.016.0144

Vico, G. (1984). The New Science. Ithaca, NJ: Cornell University Press.

\footnotetext{
How to cite this article: Russi, L., \& Rothfjell, K. (2020). Floating in Quarantine: Where Colourless Green Ideas Sleep Furiously. Anthropocenes - Human, Inhuman, Posthuman, 1(1): 8. DOl: https://doi.org/10.16997/ahip.17
}

Submitted: 18 March $2020 \quad$ Accepted: 07 April $2020 \quad$ Published: 27 May 2020

Copyright: ( $) 2020$ The Author(s). This is an open-access article distributed under the terms of the Creative Commons Attribution 4.0 International License (CC-BY 4.0), which permits unrestricted use, distribution, and reproduction in any medium, provided the original author and source are credited. See http://creativecommons.org/licenses/by/4.0/. 